Lyshol, H. (2016). Municipal public health officials and the Public Health Act. Scandinavian Journal of Vocations in Development. http://dx.doi.org/10.7577/sjvd.1796

Peer reviewed article

\title{
Municipal public health officials and the Public Health Act
}

Author:

Heidi Lyshol ${ }^{1}$

${ }^{1}$ Norwegian Institute of Public Health,

Department of Health, Statistics. P.O.Box 4404 Nydalen, N- 0403 Oslo.

heidi.lyshol@fhi.no

Key words: public health, public health coordinator, public health act, Norway 


\begin{abstract}
Introduction: The Norwegian Public Health Act of 2012 was intended to give the municipalities a bigger stake in the health of the population by emphasizing public health at a municipal level. The aim of this study was to investigate the effects of the Act on public health officials in the execution of their vocational roles.

Research questions: How do public health officials in Norwegian municipalities balance the requirements of the new Public Health Act and what their local leaders, both politicians and bureaucrats, want? How do they use the Act in the performance of their vocational roles? Does this have any relevance for vocational teachers? Method :After a literature search, semiformal interviews were conducted with 13 municipal public health officials who were also given practical tasks and short questionnaires. The interview transcripts were analysed using Thematic Analysis. This qualitative research technique is defined and described. Discussion and Results: The study shows that the public health workers see the Act as a useful tool and actively use it to leverage the public health field into greater importance. They feel that the Act is empowering, gives them greater pride in their work, and that it helps both them and their superiors to achieve greater understanding of public health workers' roles in their municipalities. Using the informants' own words, changes in the municipal public health workers' roles and vocational self-definitions are discussed in the context of the new Act and selections from the relevant literature. Conclusion: The Public Health Act has changed the roles of municipal public health workers and helped them to further public health by giving them more responsibility and expanded their duty to safeguard health in all policies. The Act is seen as empowering, giving public health professionals pride in their work and greater role understanding, and should be heavily featured in the curriculum of future public health workers.
\end{abstract}




\section{Introduction}

The Norwegian Public Health Act (Norwegian Ministry of Health and Care Services, 2012) is intended to ensure that municipalities, counties and national health authorities implement and coordinate public health measures and to facilitate long-term and systematic public health work (ibid., §1). In $\S 4$, it explicitly assigns the municipal authorities the responsibility for promoting public health in their municipalities. To fulfil this task, many municipal authorities seek assistance from a relatively new group of professionals, namely public health coordinators or public health advisors (Helgesen \& Hofstad, 2012, p42).

Organisational change may lead to changes in role and professional function, as seen in Lindberg, Christensson, and Öhrling's study from 2005. The changes they describe were caused by financial constraints and the need to save money by closing hospital wards. Less formal changes have taken place in Norway recently in the introduction of the Public Health Act (NMHCS, 2012), which moves decisions and responsibilities to a lower level in the Norwegian context, and to an unprecedented degree gives municipalities the responsibility for their citizens' public health.

Norway's 428 municipalities differ greatly in size, centrality, economic situation and political leadership. According to the Public Health Act (ibid., § 5), municipalities must have "sufficient overview" of the health of the population and of the indicators influencing health, but the Law neither states how this should be done, nor how public health work on a municipal level should be organized.

This article discusses how some professionals see their own vocational roles, how these roles have changed as a direct consequence of the Public Health Act (ibid.), and how the professionals face the challenges of their profession with a new toolset, provided by the Act. It explores how municipal public health professionals regard their professional roles and plan their activity in view of the requirements of the Act. Duchscher (2008) describes a planned process of change taking place in newly educated nurses. This paper demonstrates that public health professionals in this material perceive a similar change in themselves, driven by the Public Health Act.

It is important for vocational teachers to know how these changes have affected public health professionals, because the recent law-driven changes in the responsibilities and status of the latter, as described in Hagen (2015), must be reflected in their training to fully comply with the Public Health Act (NMHCS, 2012). The Act pinpoints the need for institutional changes, 
both explicit and implicit, as described by Schon (1995), and these public health professionals are required to be a driving force behind some of these changes.

"Health in all policies" is the official national policy (NMHCS, 2007), but local practice varies widely. Municipalities have found many different solutions, often hiring Public Health Coordinators and Public Health Advisors without a clear view of what these titles should entail and what kind of education people in these roles should have (Håbesland, 2015, p4, Helgesen \& Hofstad, 2012, p42). (Other municipalities leave the main responsibility for this work to the Chief Medical Officer, a physician who already has a set responsibility according to the Act Relating to Public Supervision of Health and Care Services (NMHCS, 1984).

While conducting a series of interviews to determine how and whether municipalities used the set of health information tools provided by the Norwegian Institute of Public Health (NIPH) in doing their jobs, the researcher heard many public health officials describe their jobs as balancing acts between the professional sectors and municipal politicians (Lyshol, 2014). These descriptions were not further debated at that time, but led to this later work. Many of them found great support in the Public Health Act (NMHCS, 2012) and used it actively to strengthen the municipal role of public health.

The aim of this article is to describe the effects of the Public Health Act on public health workers in the execution of their professional roles.

\section{Method}

In 2014, the Department of Health Statistics at the Norwegian Institute of Public Health determined that some kind of evaluation of the new public health information tools, namely the Municipal Public Health Profiles and the Municipal Data Bank, was required. It was determined that in depth interviews with representatives for different user groups in the municipal public health system would be conducted under the aegis of Dr Bernd Rechel at London School of Hygiene \& Tropical Medicine in partial fulfilment of the requirements for the Master of Public Health degree (Lyshol, 2014).

A strategic literature search (Aveyard, 2010) was carried out to search for surveys or other evaluations of similar public health profiles and databases. Other national public health authorities who have similar health information tools were contacted directly, and the grey literature was also searched. Very few evaluations, survey or quality control studies were 
identified. The most helpful studies were conducted by Statistics Canada, whose 2005 qualitative interview study and 2009 user survey about the CHS Profiles by Health Region and other health information systems provided input on both how such a survey could be conducted and what kind of questions could be resolved regarding the users and uses of health information systems. For a full overview, see Lyshol (2014).

A short questionnaire, a set of practical tasks to be accomplished using the Municipal Data Bank and an interview guide were constructed. The Regional Committee for Medical and Health Research Ethics, section South-East C, assessed the project (ref. IRB 0000 1870) and determined that the study was exempt from review and could be implemented without approval from the Committee.

All municipalities in 8 Norwegian counties (those close enough to Oslo to make it possible to conduct study visits without requiring an overnight stay, which was not within the budget) were sorted by one socio-economic indicator, namely the percentage of inhabitants aged 3039 years with only basic education. This list was split into sextiles, and one municipality from each sextile was selected at random and contacted by e-mail and telephone. Each municipality was asked to provide the contact data for two people from within the field of public health. Additional municipalities were later selected to replace the nonresponsive municipalities and municipalities where only one interview subject was provided. 7 of the 10 municipalities contacted agreed to allow some of their public health employees, a total of 12 individuals ( 6 public health coordinators, 4 public health advisors, 1 municipal medical officer with responsibility for public health, 1 director of the municipal planning department) to be interviewed.

In May - July 2014, these 12 individuals were interviewed about their work using a semistructured interview guide (Annex 1) devised by the author (Lyshol, 2014). They also filled in a short questionnaire and attempted to do specified tasks using the Municipal Data Bank (making a timeline and two different maps demonstrating some aspects of the public health of their municipality). A later reading of Schon (1995) suggests that the practical task could be regarded as an attempt to check for "knowledge-in-action". (Results from the questionnaire were deemed irrelevant to this study, and are therefore not included.)

An additional informal interview with a public health coordinator from an $8^{\text {th }}$ municipality in a different county was performed in May 2015, bringing the number of informants up to 13 . 
The informants were public health advisors, public health coordinators, municipal medical officers and municipal planners in 8 different municipalities, varying in size, political leadership, ways of organising the public health field and geographical location. They were randomly selected to give a broad range of experiences, and the additional informant (Informant 13) was later chosen to complement the earlier selection, which for pragmatic and economic reasons did not include any municipalities in Norway's three northernmost counties, where this informant works.

The public health workers and the researcher were alone during the interviews, which lasted from 25 to 70 minutes. The interviews were recorded, fully transcribed and quality checked, as described in Lyshol (2014). The recordings have been erased, as described in the consent forms, and the respondents can no longer be identified in the transcript, which for ethical reasons have been anonymised both for respondent name and municipality.

This series of semi-structured interviews primarily focused on these public health officials' use of the NIPH health information tools (ibid.), but it was noted that the respondents provided access to many other parts of their working lives via these interviews. They shared their opinions about the Public Health Act and their thoughts about local politicians and other officials they interact with in their daily work. Given a chance to confide in a stranger promising confidentiality, many of them seized the opportunity to express anonymously what they thought about the changes that had taken place in their workplaces over the last few years.

The last interview was less structured and more opportunistic, during a random encounter at work, and was not recorded. Informant 13 corrected and expanded on his/her transcribed comments by e-mail afterwards.

\section{Thematic Analysis}

Thematic Analysis (TA) is a method commonly used in qualitative research to analyse data sets, such as interview transcripts and news reports. In TA, texts are minutely studied and coded for recurring words or other patterns, and these patterns (topics) across data sets are examined and analysed in the light of the chosen research questions. Themes are bigger patterns that "recur across a dataset [and] capture something psychologically or socially meaningful" (Braun \& Clarke, 2013, p223). 
It was decided to use this method in the absence of peer-reviewed evaluations of similar public health profiles and databases (Lyshol, 2014, p15-16).

Lyshol (ibid.) used TA to find out whether and how municipal public health officials were using the health information tools from the Norwegian Institute of Public Health. During this research, several informants referred to the Public Health Act (ibid., p 25, 39, 50, 51) and described how their roles had changed, but examining this was not the purpose of the original study. TA is a way of searching for meaning (Braun \& Clarke, 2013), and in this case was an inductive approach, where the codes and themes sprung from the interviews, not from preconceived ideas about what would be important for the informants.

The random encounter with the informant from the additional municipality (Informant 13) inspired the author to look further into what the original encounters had said about the Public Health Act (NMHCS, 2012) and their vocational roles, and the anonymised original transcripts were re-examined for this purpose. A special edition of the journal Plan (Universitetsforlaget, 3-4/2015) also inspired some reflections on the changing vocational roles that municipal public health workers are experiencing.

This article, as is common in TA, lets the respondents' words speak for themselves, but also attempts to interpret them and seek hidden patterns in what is being said and what may lie behind the words (Braun \& Clarke, 2013).

The validity of TA, and its greatest strength, lies in the deep exploration of themes and topics, in providing "thick description" that strives to let the reader see what is going on, that the researcher has managed to understand the underlying meanings of the informants. (Braun \& Clarke, 2006).

Using the TA technique, the researcher does not attempt to achieve a representative selection of informants, as in quantitative research methods, as described by Goth \& Berg (2014), but rather should strive to represent the different opinions, standpoints and views of the individuals selected. Nevertheless, the phenomenon of data saturation (Guest, Bunce and Johnson, 2006, Braun \& Clarke, 2013, p55), did seem to take place, in that no new subjects were introduced by the last three informants.

It may be important to consider the power perspective in this series of interviews. The interviewer was a representative of the Norwegian Institute of Public Health, a powerful national institution which the informants knew very well from their work. To alleviate this, 
the interviewer attempted to take on a subordinate role, visiting the informants in their own offices, and emphasising the impossibility of identifying the informants in the finished research, the only part of the work that would be made accessible. The informed consent forms stressed that the original recordings would be erased after transcription, leaving only anonymised files. Many informants did seem to open up during the interviews, and several of them expressed pleasure in being allowed to say negative things about their own bosses, which probably would not have happened if they felt that their words were likely to be used against them.

Over 60 topics were identified in the original transcript material. The topics were grouped into themes, as described by Braun \& Clarke (2013), and these themes were sorted by actions, as seen in figure 2 from Lyshol (2014), below. Of particular interest for this article was topic 04, Interacting with legal frameworks, which was deemed to be a part of two different themes, both Municipal Roles and Leadership and Central Health Authority Roles.

This kind of recursive analysis, where recurring topics are seen from different angles in an attempt to understand what is really going on, is among the strongest points of TA. 


\begin{tabular}{|c|c|c|}
\hline $\begin{array}{l}\text { Municipal Use of the } \\
\text { MDB/MPHP } \\
\text { describes how the } \\
\text { municipalities use the } \\
\text { MPHPs and MDB. }\end{array}$ & $\begin{array}{l}\text { MDB/MPHP Indicator } \\
\text { Wishlist } \\
\text { lists the indicators that the } \\
\text { informants would like to } \\
\text { have. }\end{array}$ & $\begin{array}{l}\text { MDB Functionality } \\
\text { Wishlist } \\
\text { lists application issues } \\
\text { problems and problems in } \\
\text { the user/software interface. }\end{array}$ \\
\hline $\begin{array}{l}\text { Municipal Size and } \\
\text { MDB/MPHP Suitability } \\
\text { concerns issues regardins } \\
\text { municipality size and } \\
\text { indicator selection issdes } \\
\text { where municipality size prays } \\
\text { a role. }\end{array}$ & $\begin{array}{l}\text { MDB/MPHP Indicators } \\
\text { and Policy } \\
\text { describes the interaction } \\
\text { between the indicators } \\
\text { selected for the MPHPs and } \\
\text { MDB and national and } \\
\text { municipal policies. }\end{array}$ & $\begin{array}{l}\text { PHP Midsection } \\
\text { listshlist } \\
\text { informagts would like to find } \\
\text { in futyle MPHP midsections. }\end{array}$ \\
\hline $\begin{array}{l}\text { Municipal Roles and } \\
\text { Leadership } \\
\text { relates to local policy and } \\
\text { working practices. }\end{array}$ & $\begin{array}{l}\text { Central Health } \\
\text { Authokity Roles (and } \\
\text { leadership) } \\
\text { concerns national authorities } \\
\text { and how the informants see } \\
\text { their present and desired } \\
\text { roles. }\end{array}$ & $\begin{array}{l}\text { IPH Actions Wishlist } \\
\text { acts potential (non-indicator) } \\
\text { would support the } \\
\text { municipalities. }\end{array}$ \\
\hline
\end{tabular}

Abbreviations used: MDB : Municipal data bank, MPHP: Municipal Public Health Profiles NIPH: Norwegian Institute of Public Health

Figure 2 shows the main themes developed in the Thematic Analysis. The central theme, which interconnects with all the other themes, is the interaction between the indicators used in the MDB/MPHP and policy.

An example: the national childhood vaccination policy, which is to be acted upon at a municipal level, prescribes which vaccinations each child should have received by a certain age. Data on goal fulfilment (vaccination coverage) are presented in the health information presentation tools MBD/MPHP. Having this information may lead to local policies concerning how health centres, where infant vaccinations take place, should conduct their work. This may influence vaccination rates, which would be noticed by the central health authorities, and in turn be reflected in central policy-driven interventions, such as the NIPH initiative to improve municipal child vaccination rates (Lyshol, 2003). 
This central theme has effects on the other themes. Knowing that different health-related factors and outcomes are being measured may have an effect on local policy and practice the so-called Hawthorne effect (Lied \& Kazandjian, 1998). This signifies that the mere existence of an indicator could lead to municipal improvements. The Public Health Act prescribes national and municipal policy, and this analysis shows how these policies interact.

\section{Discussion and Results}

The transcripts show that on the whole, the interviewed public health professionals appreciate the Act and the way it pinpoints the added responsibility that the municipalities have for public health, as described in Nystad (2015), who emphasizes that the Act adds something new, though it was already required that the municipalities should keep public health in mind in municipal plans (ibid.) All the same, some of the informants feel that they are relatively alone in their work, and that it may be a struggle to get the overall target of public health in all policies to be included all contexts.

As stated by Informant 1: Because this is not just something that we in the administration need to understand, we must manage to convince the politicians too, that the plans we have, or are introducing, are sensible in terms of improved public health, and meanwhile we have to train the politicians, too, in relation to ... here we are not only supposed to think of the election period, here we need to think far ahead, and then we can look at municipal plans and so forth, and some politicians are very insistent that things need to happen tomorrow.

A close reading of Schön (1995) illuminates how many of the transcripts also deal with both "knowing in action" and how what is legitimate knowledge (about public health and the health of the municipal population) is "built into institutional structures and practices" (ibid.). This particular informant's words illustrate how they see their role as a change-driver, that it is their job to train the politicians (and, implicitly, the whole organisation, in the work with municipal plans).

Hoeymans et al (2014) describe a series of possible scenarios as the probable results of different policy approaches to public health. Informant 1 is discussing how politicians must be convinced that the plans introduced will be useful, and sees a contradiction in how public health work is planning for the future, while politicians want to see immediate results. What the public health officials in Informant 1's municipality seem to want, in other words, is the 
power to choose their scenario, by demonstrating to the politicians what kind of policy is desired.

Several of the public health officers interviewed work part-time in the public health field and part-time in other municipal jobs, and feel they lack time to do their jobs and miss the support of colleagues.

Informant 2 puts it like this: So... to familiarize oneself with the stuff that we are struggling with, because I... I don't have many... how do I put this, to work with in this town. Now we've got increased capacity, an increased position for the medical officer (...), that was a positive change, but I have at times been relatively alone in my field of work.

Local policy changes, though here not explicitly attributed to the Act (2012), have increased local public health capacity, but this change in responsibilities may also lead to unexpected challenges, as seen in Goth \& Økland (2016).

Putting the responsibility for public health in the health care sector may be seen as problematic:

Informant 3 says: And... I've had the job as a public health coordinator in a $25 \%$ position, and then chief municipal officer for $50 \%$, and then the rest at (local college). Eh... $25 \%$ as public health coordinator. Or, first and foremost, it's idiotic that the... health care sector has that role, and secondly, $25 \%$, that's very little.

Informant 3 also underlines the problems connected to attempting to cover the whole public health field in a part-time position. Informant 3 does not see the same positive changes that Informant 2 describes in the paragraph above, and would like the public health sector to be independent of the health care sector.

Several of the respondents stress the importance of the new Act in making their fields more important, and express hope for future inter-sectorial collaboration.

Informant 5 describes how this collaboration may take place: But now, with a new Public Health Act, the... municipality simply decided that we WILL have a policy for this, and do it properly, and then work was started to make it function, and then it was decided that I, as chief medical officer, and our public health coordinator would share the leadership and responsibility in a two-year project to make the municipality's first plan for public health.

Informant 5 here describes how his/her work and responsibilities have changed as a direct consequence of the Act. They describe the start of a process, of making institutional knowledge explicit by using municipal plans (see also Hagen, 2015) as a tool for change. 
Inter-sectorial collaboration and support from municipal leadership are seen as essential.

Informant 6 says: Yes, I... Strandbygd municipality made a choice... autumn of 2012, they've had a public health coordinator working $20 \%$, which they meant was not enough of a resource in the perspective of the obligations in the Public Health Act. That's why they constituted an inter-sectorial public health group, with all the municipal department heads, in the autumn of 2012, who said that here we need to take on the responsibility, and this is the steering group in charge, and the first thing they do is to hire a public health coordinator working $70 \%$. My mandate is quite clear, and it is that I must produce the grand overview (laughs) of Strandbygd municipality, and follow the obligations of the Act on Public Health. So we've started that process.

Informant 6 describes public health, and more specifically, this way of organising public health work in the municipality, as a political choice. Hoeymans et al. (2014) similarly describe the political processes and policy choices that may lead to their future scenarios.

Looking at the statements of the informants, the overarching trend is a guarded optimism. A process has started, inter-sectorial collaboration is taking place, and both politicians and bureaucrats are being educated about the need to work together. The Public Health Act (NMHCS 2012) is actively used to promote this work, and the public health officials are well informed about the requirements of the Act and frequently refer directly to the Act in their statements.

Using the words of the municipal public health officials, the importance of the Act cannot be overstated. The act is actively used to ensure that municipal policy is steered in a direction that the professionals in the field appreciate.

Informant 4: The stroke of genius in the Public Health Act is that it states that there is a duty to act on what we identify as the main challenges. Now we do this crossing the municipal sectors - though they haven't quite understood it yet...

"They" may here refer to both municipal leadership and to the people working within other sectors. Public health is almost sneakily introduced into new contexts, seems to be the meaning behind N's words, which express great joy in the new-found ability to insist on a public health perspective in new and widening circles. That this is an ambitious goal, is also seen by Nystad (2015).

One might return to some of Schon's (1995) words and claim that the Public Health Act (NMHCS 2012) is an explicit way to make public health "built into institutional structures and practices". The Act requires institutional learning, explicitly using the health information toolset of the NIPH, as well as making and updating municipal plans for public health.

The Public Health Act is vital to the work done by municipal public health officials, who appreciate the increased importance it gives to both public health work and their own 
professional roles. Not all municipal sectors participate to the same degree in all municipalities, but many of the informants express great hopes for the future.

Informant 6 again, on being asked about the use of health information systems to see the great picture in municipal planning: Well, er, yes, in some plans, all sectors aren't as good at using it. But I know that some sectors are very good at using it. Er... But this is a process we are working on now, and working... we are training both our administration and, and our politicians now, to know that the great overview needs to be a part of their planning strategy...

Public health officials are educating their own municipalities, including the administrative apparatus, the different professional sectors and the politicians, in ways to see the bigger picture, and the Public Health Act is one of the tools they are using to ensure that public health is an active part of all policies.

Higdem (2015) discusses how the Public Health Act (NMHCS, 2012) may be implemented in the municipalities, and suggests that collaboration between municipal planners and health professionals would be most fruitful approach (ibid., p8). This a point on which the informants behind this study would agree.

Hofstad (2015) deals with the use of another law, the Planning and Building Act (Norwegian Ministry of Local Government and Regional Development, 2008) and its use as a tool in public health work. Several informants referred to the importance of this Act (original transcripts, Lyshol, 2014), but the Public Health Act was the law that they felt brought them the greatest change - see "stroke of genius" above.

\section{Conclusion}

The Public Health Act (ibid.) is seen as very useful in municipal public health work, and its emphasis on the need for each municipality to have an overview of local conditions allows public health officials to reach a wider audience within the municipal administration than before. Many public health officials actively make use of the Act to promote greater understanding and visibility of public health within their municipalities and to ensure that the public health perspective is included in inter-sectorial work. The Act is actively used as a tool to expand the vocational roles of municipal public health workers, and intimate knowledge about how this can take place is vital to the teachers educating the next generation of public health workers. 
"Health in all policies" is not a cliché in municipal public health, and as described by the informants, inter-sectorial collaborations are helping municipalities to reach this lofty goal.

The Public Health Act (ibid.) is found to be of great help to municipal public health professionals in three different areas: Empowerment, Pride in their work and Role understanding.

\section{Conflict of interest}

The author declares no conflict of interest. 


\section{Literature}

Aveyard, H. (2010). Doing a literature review in health and social care: A practical guide. Maidenhead: McGraw-Hill International.

Braun, V., \& Clarke, V. (2006). Using thematic analysis in psychology. Qualitative research in psychology, 3(2), 77-101.

Braun, V., \& Clarke, V. (2013). Successful qualitative research: A practical guide for beginners. Thousand Oaks,CA: Sage.

Duchscher, J. B. (2008). A process of becoming: The stages of new nursing graduate professional role transition. The Journal of Continuing Education in Nursing, 39(10), 441-450.

Goth, U.S. \& Berg, J. (2014) Metodiske utfordringer. In U.S. Goth (Ed.) Folkehelse i et norsk perspektiv. Oslo: Gyldendal akademisk.

Goth, U.S. \& Økland, Ø. (2016) Helse- og oppvekstfag i en globalisert verden. In U.S.

Goth (Ed.), Yrkes- og profesjonsutdanning i en norsk kontekst (pp. 68-83). Oslo:

Gyldendal akademisk.

Guest, G., Bunce, A. \& Johnson, L. (2006). How many interviews are enough? An experiment with data saturation and variability. Field methods 18(1), 59-82.

Hagen, S. (2015). Folkehelse og plan i kommunene. Tidsskrift for samfunnsplanlegging Plan (3-4), 44-45.

Higdem, U. (2015). Møtet mellom helse og plan. Tidsskrift for samfunnsplanlegging Plan (34), 4-9.

Hoeymans, N., van Loon, A.J.M., van den Berg, M. , Harbers, M.M. , Hilderink, H.B.M., van Oers, J.A.M. , Schoemaker, C.G. (2014). A healthier Netherlands: Key findings from the Dutch 2014 Public Health Status and Foresight Report. National Institute for Public Health and the Environment (RIVM), Bilthoven. Available from: http://eurohealthnet.eu/sites/eurohealthnet.eu/files/A\%20healthier $\% 20$ Netherlands, $\% 2$ 0PH\%09SF-2014.pdf

Hofstad, H. (2015). Plan- og bygningsloven som verktøy i folkehelsearbeidet: Ambisiøst eller urealistisk?. Tidsskrift for samfunnsplanlegging Plan (3-4), 10-14

Helgesen, M.K., \& Hofstad, H. (2012). Regionalt og lokalt folkehelsearbeid. Ressurser, organisering og koordinering. En baselineundersøkelse. NIBR-rapport 2012:13. Oslo: Norsk Institutt for by- og regionforskning.

Håbesland, G. (2015). Folkehelsekoordinatoren - styrking av det tverrsektorielle folkehelsearbeidet. Master thesis at NTNU, Trondheim. Available from: http://hdl.handle.net/11250/298819

Lied, T.R. \& Kazandjian, V.A. (1998). A Hawthorne strategy: implications for performance measurement \& improvement. Clinical performance a. quality health care (6)201-204. 
Lindberg, I., Christensson, K., \& Öhrling, K. (2005). Midwives' experience of organisational and professional change. Midwifery, 21(4)355-364.

Lyshol, H. (2003). Improving the Norwegian childhood vaccination register. European Journal of Public Health 2003;13 (4)57-57.

Lyshol, H. (2014). Use of Norwegian Municipal Public Health Profiles and Data Bank: A qualitative study. London: London School of Hygiene and Tropical Medicine Available from: https://brage.bibsys.no/xmlui/handle/11250/223417

Norwegian Ministry of Health and Care Services (1984). Act relating to public supervision of health and care services. ACT-1984-03-30-15. [Lovdata]. Oslo.

Norwegian Ministry of Health and Care Services (2007). National strategy to reduce social inequalities in health. Report no. 20 to the Storting. Oslo.

Norwegian Ministry of Health and Care Services (2012). The Public Health Act. ACT-2011-“ 06-24-29. [Lovdata]. Oslo.

Available from: http://www.ub.uio.no/ujur/ulovdata/lov-20110624-029-eng.pdf

Norwegian Ministry of Local Government and Regional Development (2008). The Planning and Building Act. ACT-2008-27-06-71. [Lovdata]. Oslo.

Nystad, J. F. (2015). Folkehelse + planlegging = sant?. Tidsskrift for samfunnsplanlegging Plan (3-4) 2

Schön, D. A.(1995). The new scholarship requires a new epistemology. Change. Nov/Dec95, Vol. 27 (6) 26-35.

Statistics Canada (2005). Marketing Research Final Report. Consultation Study. External Clients of Health Statistics Division.

Statistics Canada (2009). Consultation Study on Health Indicators: Initial Findings. Available from: http://www.statcan.gc.ca/eng/start 
[This has been translated from the original in Norwegian.]

[It is important to emphasize that this is not a questionnaire, but a guide to topics that could be raised during the interviews.]

1) Demographic questions (to be filled in in advance)

a. The Municipality
i. Name
ii. Population
iii. District index, Centrality
iv. The specific MPHP (to be brought)
v. Downloads (how many times)
vi. Main industries (if available on municipal web page)
vii. How public health work is organised (if available on municipal web page)

b. The Informant
i. Name
ii. Gender
iii. Age
iv. Education
v. Job title
vi. Time in position

2) About the Municipal Public Health Profile (MPHP)
a. How/when did you find out about the MPHP?
b. What kind of work do you have where statistics can be of use?
c. Do you use the MPHP at all?
d. How much?
e. When did you last use the MPHP?
f. For what purpose? Result?
g. In general: How often?
h. For what?
i. Example?
j. Easy/hard compared to other data sources?
$\mathrm{k}$. What do you think about the presentation form?
1. Do you use the MPHP with others?
$\mathrm{m}$. Have you shared the MPHP with anyone? Who? What and how?
n. Does anyone else in the municipality use the MPHP?
o. Effect of the MPHP locally?
p. Do you check the MPHP every year regarding municipal developments? 
q. Is the MPHP mirrored in municipal policy/strategy?

r. How COULD one use the MPHP?

s. What kind of work do you have where the MPHP might be of use?

t. Do you/your municipality produce your own statistics?

u. Do you/your municipality use other sources of statistics?

v. Does the MPHP reflect your reality?

w. Reflection page 1 ?

$\mathrm{x}$. Reflection page 2 ?

y. Reflection page 3?

z. Reflection page $4 /$ the barometre?

aa. What do you think about the length of the MPHP?

bb. Comments user friendliness/functionality?

cc. Comments data provided/indicators? Are they relevant?

dd. Are you satisfied with the MPHP?

3) About the Municipal Data Bank (MBD)

a. What kind of work do you have where statistics can be of use?

b. Do you use statistics banks, such as Statistics Norway's data bank, NorHealth, WHO-HfA etc in your daily work?

c. How/when did you find out about the MDB?

d. Do you use the MDB at all?

e. When did you last use the MDB? Result?

f. How much do you use the MDB?

g. In general: How often?

h. For what? Example use?

i. Easy/hard compared to other data sources?

j. What do you think about the presentation form?

k. Do you use the MDB with others?

1. Have you shared the MDB with anyone? Who? What and how?

$\mathrm{m}$. Does anyone else in the municipality use the MDB?

n. Effect of the MDB locally?

o. Is the MDB mirrored in municipal policy/strategy?

p. How COULD one use the MDB?

q. What kind of work do you have where the MDB might be of use?

r. Do you/your municipality produce your own statistics?

s. Do you/your municipality use other sources of statistics?

t. Does the MDB reflect your reality?

u. Comments user friendliness/functionality?

v. Comments data provided/indicators? Are they relevant?

w. Are you satisfied with the MDB? 
4) For the future
a. What can be improved in the MPHP?
b. Data selection/indicators in the MPHP?
c. Other data sources for the MPHP?
d. User friendliness in the MPHP?
e. What can be improved in the MDB?
f. Data selection/indicators in the MDB?
g. Other data sources for the MDB?
h. User friendliness in the MDB?
i. How can the MPHP and MDB better serve your needs and the municipality's needs?
j. Is there a need for other products for data presentation?
$\mathrm{k}$. Is the NIPH sufficiently active in promoting the MPHP/MDB?
1. What should the NIPH be doing?

5) Any other issues you would like to raise? 